\title{
Iron Transport in Mycobacterium smegmatis: Uptake of Iron from Ferriexochelin
}

\author{
By MARIS C. STEPHENSON AND COLIN RATLEDGE \\ Department of Biochemistry, University of Hull, Hull HU6 7RX
}

(Received 28 June 1978)

\begin{abstract}
Exochelins are a group of extracellular iron chelators produced by mycobacteria. Iron uptake by washed suspensions of iron-deficiently grown Mycobacterium smegmatis from ${ }^{55} \mathrm{Fe}(\mathrm{III})$-exochelin fractions (at about $1 \mu \mathrm{M}$ ) was greatest from the fractions containing the compounds that naturally predominate in culture filtrates. Uptake from the major fraction, as well as from combined exochelins, had a $K_{\mathrm{m}}$ of about $6 \mu \mathrm{M}$ and was unaffected by the presence of a large excess of desferriexochelin; it was inhibited by more than $90 \%$ by electron transport inhibitors, uncouplers of oxidative phosphorylation, thiol reagents and by anaerobiosis and low temperature. Uptake of iron from ${ }^{55} \mathrm{Fe}$-salicylate, which is mediated by mycobactin, was insensitive to these inhibitors and a 10 -fold excess of ferric salicylate did not inhibit ${ }^{55} \mathrm{Fe}$-exochelin uptake. Thus mycobactin is probably not involved in the transport of iron from ferriexochelin at physiological concentrations. The rate of uptake of iron from ${ }^{55} \mathrm{Fe}$-exochelin into iron-sufficiently grown cells, which contain less than $0.05 \%$ of the concentration of mycobactin found in iron-deficiently grown cells, was only slightly lower than the rate of uptake into iron-deficiently grown cells.

Uptake of ferri $\left[{ }^{3} \mathrm{H}\right]$ exochelin, which could only be carried out at high and probably nonphysiological concentrations (about $60 \mu \mathrm{M}$ ), was also extremely sensitive to metabolic inhibitors suggesting that the whole complex was being transported. At these high external concentrations of ferriexochelin a second, non-saturable, inhibitor-insensitive iron uptake process occurred. This process was inhibited in iron-deficiently grown cells by ferric salicylate and may therefore involve mycobactin. A similar but not identical second system which was not sensitive to ferric salicylate was found in iron-sufficiently grown cells; this might indicate yet another pathway of iron uptake from ferriexochelin.
\end{abstract}

\section{INTRODUCTION}

Ratledge \& Marshall (1972) proposed a mechanism for the uptake of iron into Mycobacterium smegmatis which involved the mediation of mycobactin (Snow, 1970), a lipidsoluble iron-binding agent, in shuttling iron across the boundary layers of the cell. The loading of iron on to mycobactin was presumed to be via salicylic acid, a compound which had previously been isolated from culture filtrates of iron-deficiently grown $M$. smegmatis (Ratledge \& Winder, 1962). As salicylate was subsequently shown not to fulfil this role in the presence of phosphate ions, due to the formation of insoluble ferric phosphate (Ratledge et al., 1974), we searched for, and found, an extracellular iron chelator which would hold iron in solution in the presence of competing ions. This chelator was subsequently shown to consist of a group of compounds which were termed exochelins (Macham \& Ratledge, 1975; Macham et al., 1975). Exochelins from $M$. smegmatis can solubilize iron from ferric phosphate and ferritin and mediate the uptake of iron by $M$. smegmatis (Macham et al., 1977). We have now investigated this process of iron transport from ferriexochelin. A preliminary communication of part of this work has appeared elsewhere (Stephenson \& Ratledge, 1978). 


\begin{abstract}
METHODS
Abbreviations. CCCP, Carbonyl cyanide $m$-chlorophenylhydrazone; DNP, 2,4-dinitrophenol; NEM, $N$-ethylmaleimide.

Organism, growth and preparation of washed suspensions. Mycobacterium smegmatis NCIB 8548 was grown in $100 \mathrm{ml}$ medium (Ratledge \& Hall, 1971) in $250 \mathrm{ml}$ conical flasks, with shaking, at $37^{\circ} \mathrm{C}$. For iron-deficient growth $0.05 \mu \mathrm{g} \mathrm{Fe}^{2+} \mathrm{ml}^{-1}$ was added to the medium; for iron-sufficient growth $2.0 \mu \mathrm{g} \mathrm{Fe}^{2+} \mathrm{ml}^{-1}$ was added. Cells were harvested after $3 \mathrm{~d}$ by filtering through Whatman GF/C $(70 \mathrm{~mm})$ glass-fibre filters and were washed with $0.85 \%(\mathrm{w} / \mathrm{v}) \mathrm{NaCl}$ containing $1.0 \%(\mathrm{v} / \mathrm{v})$ Tween 80 . They were then resuspended in an identical solution at approximately $60 \mathrm{mg}^{\mathrm{dry} \mathrm{wt} \mathrm{ml}} \mathrm{ml}^{-1}$ for iron-deficiently grown cells and $80 \mathrm{mg}$ dry wt ml-1 for ironsufficiently grown cells and were stored on ice until needed. Rates of iron transport were stable over $3 \mathrm{~h}$ storage.

Exochelins. Exochelin MS was isolated and purified as described previously (Macham et al., 1977), as were the preparations of desferri- and ${ }^{55} \mathrm{Fe}$-exochelin. Tritiated exochelin was prepared by adding $\beta-\left[3-{ }^{3} \mathrm{H}\right]-$ alanine (sp.act. $49 \mathrm{Ci} \mathrm{mmol}^{-1}$ ) to iron-deficient growth medium at $1.02 \mathrm{nmol}$ per $100 \mathrm{ml}$ medium, at the time of inoculation. After $3 \mathrm{~d}$ growth, the exochelin was isolated as described previously for unlabelled exochelin and the purification was taken to the stage of preparation of the 'purified but unfractionated material' (Macham et al., 1977).
\end{abstract}

Preparation of ${ }^{55} \mathrm{Fe}$-salicylate. To a solution of ${ }^{55} \mathrm{FeCl}_{3}$ containing $0.254 \mu \mathrm{mol} \mathrm{Fe}$ (sp.act. $93.5 \mu \mathrm{Ci} \mu \mathrm{mol}^{-1}$ ), salicylic acid $(8 \cdot 5 \mu \mathrm{mol})$ was added. (This was the equivalent of an 11-fold excess of salicylate since salicylate and iron bind in the molar ratio of 3:1.) $\mathrm{MgSO}_{4}$ was then added to give a final concentration of $1 \mathrm{~mm}$, the solution was adjusted to $\mathrm{pH} 7.0$ with $0.1 \mathrm{M}$-Tris and the volume was adjusted to $20 \mathrm{ml}$, so that the initial concentration of $\mathrm{Fe}(\text { salicylate) })_{3}$ was $12 \cdot 7 \mu \mathrm{M}$. The solution was filtered through a Whatman GF/A $(25 \mathrm{~mm})$ glass-fibre filter and used immediately for transport assays. Solutions were prepared daily.

Uptake of ${ }^{55} \mathrm{Fe}$ from ${ }^{55} \mathrm{Fe}$-exochelin. Initial rates of iron uptake into washed suspensions of $3 \mathrm{~d}$-old cultures

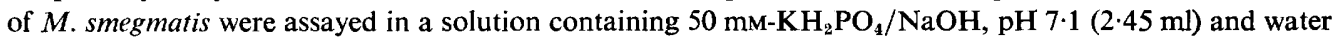
or other component $(0.35 \mathrm{ml})$. This solution was incubated for $5 \mathrm{~min}$ in a $25 \mathrm{ml}$ Erlenmeyer flask in a shaking waterbath at $25^{\circ} \mathrm{C}$. The washed suspension $(0.35 \mathrm{ml}$, see above) was then added and the incubation was continued for a further $10 \mathrm{~min}$ before ${ }^{55} \mathrm{Fe}$-exochelin $(0.35 \mathrm{ml})$, pre-warmed to $25^{\circ} \mathrm{C}$, was added by syringe. Using an automatic pipette, samples $(0.5 \mathrm{ml})$ were run into modified Millipore Swinnex-25 filter units holding a Whatman GF/A $(25 \mathrm{~mm})$ glass-fibre filter and $2 \mathrm{ml} 50 \mathrm{~mm}-\mathrm{Na}_{2}$ EDTA, $\mathrm{pH} 6.0$, at room temperature. Suction was immediately applied to the filter disc to drain it completely. The filter was washed with a further $2 \times 1 \mathrm{ml}$ of EDTA solution, removed immediately, placed in a glass scintillation vial and dried in an oven at $108^{\circ} \mathrm{C}$. Soluene $100\left(0.5 \mathrm{ml}\right.$, Packard Instruments) was added to each vial before incubating at $60^{\circ} \mathrm{C}$ for $5 \mathrm{~h}$ to digest the bacteria. Glacial acetic acid $(50 \mu \mathrm{l})$ and scintillation fluid $(10 \mathrm{ml})$ were added to each vial before counting (see below). Initial rates of uptake, expressed as nmol $\min ^{-1}\left(\mathrm{~g}\right.$ dry wt) ${ }^{-1}$, were measured in duplicate from four samples taken during the first $2 \mathrm{~min}$ after the addition of ${ }^{55} \mathrm{Fe}$-exochelin.

Uptake of ${ }^{55} \mathrm{Fe}$ from ${ }^{55} \mathrm{Fe}$-salicylate. Experiments were performed as described above for ${ }^{55} \mathrm{Fe}$-exochelin except that the $\mathrm{KH}_{2} \mathrm{PO}_{4} / \mathrm{NaOH}$ buffer was replaced by $0 \cdot 1 \mathrm{M}$-Tris/ $\mathrm{HCl}$ buffer, $\mathrm{pH} 7 \cdot 0$.

Uptake of $\left[{ }^{3} \mathrm{H}\right]$ exochelin. Experiments were performed as described above for ${ }^{55} \mathrm{Fe}$-exochelin except that initial rates were measured in duplicate from four samples taken during the first 15 min after the addition of ferri $\left[{ }^{3} \mathrm{H}\right]$ exochelin. The washed filters were placed directly into $10 \mathrm{ml}$ scintillation fluid (see below). Rates of ${ }^{3} \mathrm{H}$ uptake were converted to rates of iron transport on the basis that the ferriexochelin complex contains equimolar concentrations of iron and exochelin.

Counting of radioactivity. (i) ${ }^{55} \mathrm{Fe}$. Aqueous samples for the determination of specific activities were dried in glass scintillation vials and treated in an identical manner to the dried filters from transport assays (see above). Samples were counted in a scintillation fluid comprising $10 \%(w / v)$ naphthalene and $1 \%(w / v)$ 2,5-diphenyloxazole in toluene.

(ii) ${ }^{3} \mathrm{H}$. Aqueous samples for the determination of specific activities and filters from transport assays were counted directly in a scintillation fluid comprising: xylene, $726 \mathrm{ml}$; Triton N-101, $264 \mathrm{ml} ; 2$-(4'-tert-butylphenyl)-5-(4"-biphenylyl)-1,3,4-oxadiazole, $10 \mathrm{~g}$.

\title{
RESULTS
}

\section{Iron uptake from various exochelin fractions}

The uptake of ${ }^{55} \mathrm{Fe}$ from unfractionated but purified ${ }^{55} \mathrm{Fe}$-exochelin $(1 \cdot 25 \mu \mathrm{M})$ into washed suspensions of iron-deficiently grown $M$. smegmatis, held in $50 \mathrm{~mm}-\mathrm{KH}_{2} \mathrm{PO}_{4} / \mathrm{NaOH}$ buffer, pH $7 \cdot 1$, reached a constant value after $12 \mathrm{~min}$ (Fig. 1). The amount of iron accumulated at 


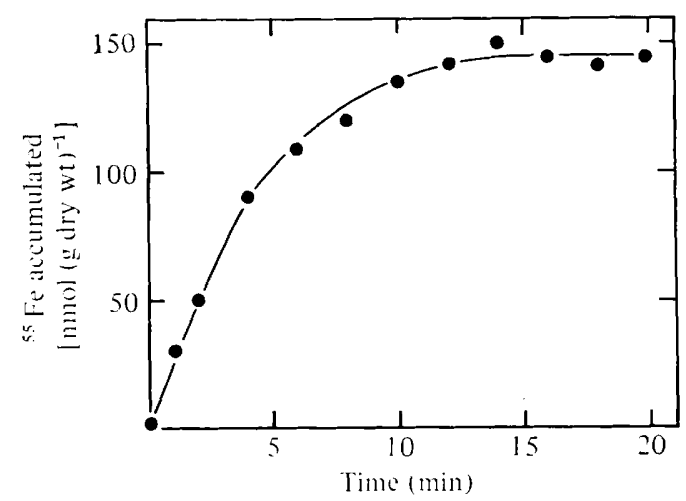

Fig. 1. Uptake of ${ }^{55} \mathrm{Fe}$ from ferriexochelin by iron-deficiently grown Mycobacterium smegmatis. Transport was assayed as described in Methods. Unfractionated ${ }^{55} \mathrm{Fe}$-exochelin was added at a final concentration of $1.25 \mu \mathrm{M}$.

the plateau represented about a 60 -fold increase over the external iron concentration, assuming an intracellular volume of $2 \mathrm{ml}(\mathrm{g} \text { dry } \mathrm{wt})^{-1}$ (a typical value for bacteria; see, for example, Midgley \& Dawes, 1973).

Exochelin MS is a mixture of at least seven components which are separable by ionexchange chromatography (Macham et al., 1977). When the ability of the different fractions to transport ${ }^{55} \mathrm{Fe}(1 \cdot 7 \mu \mathrm{M})$ into $M$. smegmatis was compared, fractions 1 and 2 combined had the same activity as the unfractionated exochelins [i.e. $34 \mathrm{nmol} \mathrm{min}^{-1}(\mathrm{~g} \text { dry wt })^{-1}$ ] whereas fraction 3 had a slightly higher activity [ $46 \mathrm{nmol} \min ^{-1}(\mathrm{~g} \text { dry wt })^{-1}$ ] and fraction 4 a slightly lower activity $\left[21 \mathrm{nmol} \min ^{-1}\left(\mathrm{~g}^{\mathrm{dry}} \mathrm{wt}\right)^{-1}\right]$. Fractions 5 and 6 were inactive or

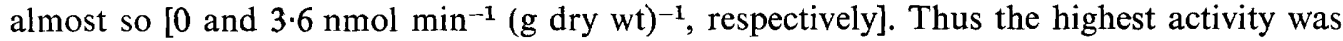
shown by the major fraction 3 which constitutes about $75 \%$ of the total exochelin. Fraction $3 \mathrm{~A}$, obtained by further purification of fraction 3 , exhibited an almost identical activity to fraction 3 itself. The relative inactivity of fractions 5 and 6 may indicate that they are breakdown products of the major exochelins.

\section{Uptake in the presence of desferriexochelin}

The concentration of ferriexochelin used in these experiments $(1 \cdot 7 \mu \mathrm{M})$ was equivalent to an exochelin concentration of about $1.3 \mu \mathrm{g} \mathrm{ml}^{-1}$, assuming a molecular weight of 800 . This is similar to the physiological concentrations of ferriexochelin which are found in the medium during growth of $M$. smegmatis under iron-deficient conditions. Although the amount of desferriexochelin isolated from spent growth medium is about $50 \mu \mathrm{g} \mathrm{ml}^{-1}$, the amount of ferriexochelin present during growth will be limited by the supply of iron. As the total iron concentration (added plus residual) is about $0 \cdot 1 \mu \mathrm{g} \mathrm{ml}^{-1}$, ferriexochelin cannot exceed about $1.4 \mu \mathrm{g} \mathrm{ml}^{-1}$.

There was no inhibition of iron uptake when ${ }^{55} \mathrm{Fe}$-exochelin (at $1 \cdot 1 \mu \mathrm{M}$ ) was added to bacterial suspensions to which a large excess of desferriexochelin $\left(50 \mu \mathrm{g} \mathrm{ml}^{-1}\right)$ had been added to mimic the probable growth conditions. Thus there was no competition between ferriexochelin and desferriexochelin for a possible receptor site.

\section{Sensitivity of iron uptake to inhibitors}

At these low, physiological, external ferriexochelin concentrations, ${ }^{55} \mathrm{Fe}$ uptake into irondeficiently grown cells was inhibited by more than $90 \%$ by the electron transport inhibitors $\mathrm{NaN}_{3}$ and $\mathrm{KCN}$, by the uncouplers CCCP and DNP, and by the thiol reagent $\mathrm{HgCl}_{2}$ (Table 1). Uptake was also virtually eliminated by anaerobiosis and low temperature $\left(4^{\circ} \mathrm{C}\right)$. Similar levels of inhibition-occurred whether the purified fraction 3 (or $3 \mathrm{~A}$ ) or the unfrac- 
Table 1. Effect of various potential inhibitors on iron transport from ferriexochelin, at low external concentrations, by Mycobacterium smegmatis

Transport was assayed as described in Methods. Iron-deficiently and iron-sufficiently grown cells were incubated with the potential inhibitors for $10 \mathrm{~min}$ before adding the various ${ }^{55} \mathrm{Fe}$-exochelin fractions (Unf, unfractionated exochelin) at the concentrations shown. The results were compiled from several experiments in which $100 \%$ activity with iron-deficiently grown cells was in the range 17 to $44 \mathrm{nmol} \mathrm{min}^{-1}$ (g dry wt) ${ }^{-1}$ for fraction $3 \mathrm{~A}, 28$ to $52 \mathrm{nmol} \mathrm{min}^{-1}$ ( $\mathrm{g}$ dry wt) ${ }^{-1}$ for fraction 3 and 37 to $72 \mathrm{nmol} \mathrm{min}^{-1}$ ( $\mathrm{g}$ dry $\left.\mathrm{wt}\right)^{-1}$ for the unfractionated exochelin at the various concentrations used; $100 \%$ activity with the iron-sufficiently grown cells was in the range 18 to $39 \mathrm{nmol} \mathrm{min}-1$ (g dry wt) $)^{-1}$.

\begin{tabular}{|c|c|c|c|c|c|c|}
\hline \multirow[b]{2}{*}{ Inhibitor } & \multirow[b]{2}{*}{ in fraction ... } & \multicolumn{5}{|c|}{ Relative initial rate of uptake } \\
\hline & & $\begin{array}{c}3 \mathrm{~A} \\
(0 \cdot 36 \mu \mathrm{M}) \\
\text { Iron- } \\
\text { deficient }\end{array}$ & $\begin{array}{c}3 \\
(1 \cdot 3 \mu \mathrm{M}) \\
\text { Iron- } \\
\text { deficient }\end{array}$ & $\begin{array}{c}\text { Unf. } \\
(1 \cdot 3 \mu \mathrm{M}) \\
\text { Iron- } \\
\text { deficient }\end{array}$ & $\begin{array}{c}\text { Unf. } \\
(1.8 \mu \mathrm{M}) \\
\text { Iron- } \\
\text { deficient }\end{array}$ & $\begin{array}{c}\text { Unf. } \\
(1.8 \mu \mathrm{M}) \\
\text { Iron- } \\
\text { sufficient }\end{array}$ \\
\hline None & 一 & 100 & 100 & 100 & 100 & 100 \\
\hline $\mathrm{KCN}$ & $\begin{array}{r}1 \\
10\end{array}$ & $\begin{array}{r}21 \\
5\end{array}$ & $-\overline{3}$ & $\begin{array}{r}29 \\
4\end{array}$ & $-\frac{}{6}$ & $-\frac{}{8}$ \\
\hline $\mathrm{NaN}_{3}$ & $\begin{array}{r}5 \\
30\end{array}$ & $\begin{array}{r}30 \\
2\end{array}$ & $-\overline{4}$ & $\begin{array}{r}31 \\
3\end{array}$ & $-\frac{}{7}$ & $\overline{5}$ \\
\hline $\mathrm{CCCP}$ & $\begin{array}{l}0 \cdot 01 \\
0 \cdot 10\end{array}$ & $\begin{array}{r}56 \\
5\end{array}$ & $\overline{2}$ & $\begin{array}{r}49 \\
3\end{array}$ & -- & - \\
\hline DNP & 2 & 7 & 9 & 3 & 8 & 10 \\
\hline NEM & $0 \cdot 1$ & 49 & 56 & 51 & 52 & 58 \\
\hline $\mathrm{HgCl}_{2}$ & $0 \cdot 1$ & 3 & 7 & 4 & 11 & 9 \\
\hline $\mathrm{N}_{2}$ atmosphere & 一 & 2 & 5 & 3 & 一 & - \\
\hline Temp. $4 \mathrm{C}$ & 一 & 0 & 2 & 0 & 4 & 3 \\
\hline
\end{tabular}

tionated material was used. Thus the latter material was used in most of the subsequent experiments as its overall characteristics were typical of the major, most active fraction. Difficulties in producing large quantities of the purified fraction $3 \mathrm{~A}$ precluded using it in large numbers of routine assays. When iron-sufficiently grown cells were used, initial rates of ${ }^{55} \mathrm{Fe}$ uptake from ferriexochelin $(1.8 \mu \mathrm{M})$ were only two- to threefold lower than those of the iron-deficiently grown cells and inhibition studies revealed essentially similar results with both types of organism (Table 1).

\section{Investigation of the role of mycobactin}

The inhibitor-sensitivity of iron uptake from ${ }^{55} \mathrm{Fe}$-salicylate was compared with that of iron uptake from ferriexochelin since the uptake of iron from ${ }^{55} \mathrm{Fe}$-salicylate by irondeficiently grown $M$. smegmatis is mediated by mycobactin (Ratledge \& Marshall, 1972). However, the uptake of ${ }^{55} \mathrm{Fe}$ from ${ }^{55} \mathrm{Fe}$-salicylate $(1.27 \mu \mathrm{M})$ in $0.1 \mathrm{M}$-Tris $/ \mathrm{HCl}$ buffer, $\mathrm{pH} 7.0$ (phosphate buffer cannot be used as insoluble ferric phosphate is quickly produced) was markedly different from iron uptake from ferriexochelin, being insensitive to $\mathrm{KCN}(10 \mathrm{mM})$, CCCP $(0.1 \mathrm{~mm})$ and $\mathrm{HgCl}_{2}(0 \cdot 1 \mathrm{mM})$ in both iron-deficiently and iron-sufficiently grown cells. (Initial rates of ${ }^{55} \mathrm{Fe}$ uptake from ${ }^{55} \mathrm{Fe}$-salicylate in iron-sufficiently grown cells were about threefold lower than those in the iron-deficiently grown cells.) These results suggest that different mechanisms operate for the uptake of iron from ferric salicylate and ferriexochelin. Supporting this suggestion, no inhibition of ${ }^{55} \mathrm{Fe}$ uptake from ${ }^{55} \mathrm{Fe}$-exochelin $(1.25 \mu \mathrm{M})$ by iron-deficiently grown cells was observed when unlabelled ferric salicylate $(12.5 \mu \mathrm{M})$ was added, as a possible competitor for the receptor site, $15 \mathrm{~s}$ prior to adding the labelled substrate. 


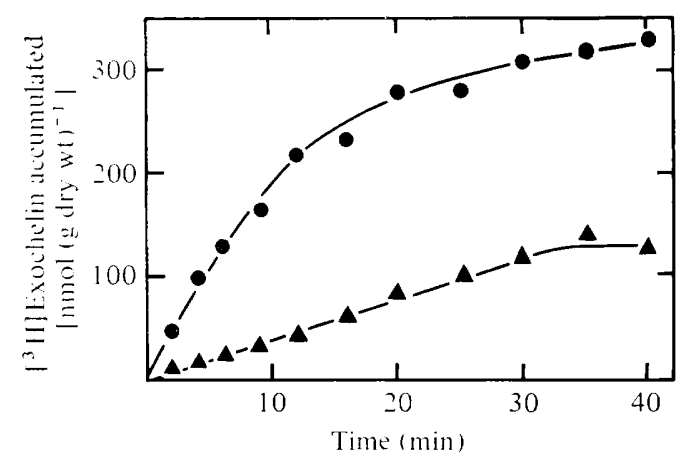

Fig. 2

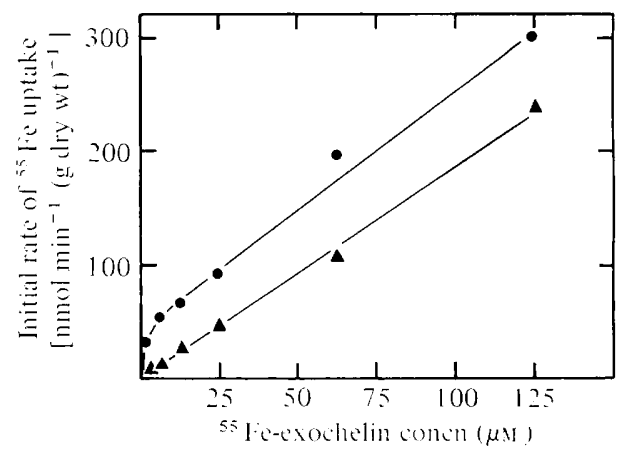

Fig. 3

Fig. 2. Uptake of $\left[{ }^{3} \mathrm{H}\right]$ exochelin by Mycobacterium smegmatis grown iron-deficiently (O) or ironsufficiently $(\boldsymbol{\Delta})$. Transport was assayed as described in Methods. Unfractionated ferri $\left[{ }^{3} \mathrm{H}\right]$ exochelin was added at a final concentration of $71 \mu \mathrm{M}$.

Fig. 3. Uptake of ${ }^{55} \mathrm{Fe}$ by iron-deficiently grown Mycobacterium smegmatis in response to the external ferriexochelin concentration, in the absence $(\boldsymbol{O})$ or presence $(\boldsymbol{A})$ of $\mathrm{NaN}_{3}$. Transport was assayed as described in Methods. Cells were preincubated with $\mathrm{NaN}_{3}(30 \mathrm{~mm})$ for 10 min prior to the addition of unfractionated ${ }^{55} \mathrm{Fe}$-exochelin.

Thus we concluded that iron uptake from ferriexochelin at physiological concentrations was a process in some way dependent on metabolism, as evidenced by its sensitivity to a wide range of metabolic inhibitors and anaerobiosis, which did not involve mediation by the lipid-soluble iron-binding compound mycobactin.

\section{Studies on the uptake of ferri $\left[{ }^{3} \mathrm{H}\right]$ exochelin}

Iron uptake from ferriexochelin could involve uptake of the entire complex or release of iron from the complex without necessitating uptake of the chelator into the cell. To investigate the uptake process, attempts were made to prepare radioisotopically labelled exochelins by growing $M$. smegmatis in the presence of a suitably labelled precursor of exochelin. Exochelin fraction $3 \mathrm{~A}$ contains moieties of lysine, $\beta$-alanine and threonine $(\mathrm{L}$. $\mathrm{P}$. Macham, M. C. Stephenson \& C. Ratledge, unpublished work). We therefore initially tried adding $L_{-}\left[\mathrm{U}^{14} \mathrm{C}\right]$ lysine (sp.act. $0 \cdot 1 \mathrm{mCi} \mathrm{mmol}^{-1}$ ) at $1 \mu \mathrm{mol} \mathrm{ml}^{-1}$ to cultures of iron-deficiently growing $M$. smegmatis, but the recovered exochelin had too low a specific activity [about 150 c.p.m. ( $\mu$ g exochelin $)^{-1}$ ] to allow useful experiments to be conducted. Addition of $\beta$ - $\left[3-{ }^{3} \mathrm{H}\right]$ alanine (sp.act. $49 \mathrm{mCi} \mathrm{nmol}^{-1}$ ) to the growth medium at $10 \cdot 2 \mathrm{pmol} \mathrm{ml}^{-1}$ produced a purified but unfractionated exochelin with a specific activity of 650 c.p.m. ( $\mu$ g exochelin) $)^{-1}$, showing that considerable dilution with exogenous $\beta$-alanine had occurred. This exochelin preparation, though of lower specific activity than had been hoped for, was sufficiently active to enable assays of exochelin uptake to be conducted provided that the external exochelin concentration was increased to about $60 \mu \mathrm{M}$. At such high external concentrations $\left[{ }^{3} \mathrm{H}\right]$ exochelin was accumulated from ferri $\left[{ }^{3} \mathrm{H}\right]$ exochelin by both iron-deficiently and ironsufficiently grown $M$. smegmatis (Fig. 2), the rate of iron uptake by the former being about three times that by the latter, in keeping with previous data for ${ }^{55} \mathrm{Fe}$ uptake from ferriexochelin (see Table 1). However, a comparison of the absolute rates of ${ }^{3} \mathrm{H}$ uptake using ferri $\left[{ }^{3} \mathrm{H}\right]$ exochelin and ${ }^{55} \mathrm{Fe}$ uptake using ${ }^{55} \mathrm{Fe}$-exochelin (both at $62 \mu \mathrm{M}$ ) revealed that rates of ${ }^{55} \mathrm{Fe}$ uptake were 10 - to 20 -fold higher than rates of ${ }^{3} \mathrm{H}$ uptake. Thus the amount of iron transported as the ferriexochelin complex accounted for only 5 to $10 \%$ of the total iron accumulated with both iron-deficiently and iron-sufficiently grown cells. An explanation for this discrepancy became apparent from the work described below. 
Table 2. Effect of various potential inhibitors on iron transport from ferriexochelin, at high external concentrations, by Mycobacterium smegmatis

The assays were performed as described in the legend to Table 1 . The unfractionated ${ }^{55} \mathrm{Fe}$-exochelin concentration was $50 \mu \mathrm{M}$ in both sets of experiments and $100 \%$ activity was in the range 105 to $168 \mathrm{nmol} \mathrm{min}^{-1}\left(\mathrm{~g}\right.$ dry wt) ${ }^{-1}$ for iron-deficiently grown cells and 48 to $89 \mathrm{nmol} \mathrm{min}^{-1}\left(\mathrm{~g}\right.$ dry wt) ${ }^{-1}$ for iron-sufficiently grown cells.

$\begin{array}{lccc}\text { Inhibitor } & \text { Concn (mM) } & \text { Iron-deficient } & \text { Iron-sufficient } \\ \text { None } & - & 100 & 100 \\ \mathrm{KCN} & 10 & 42 & 38 \\ \mathrm{NaN}_{3} & 30 & 68 & 71 \\ \mathrm{CCCP} & 0 \cdot 1 & 84 & 80 \\ \mathrm{DNP} & 2 & 73 & 78 \\ \mathrm{HgCl}_{2} & 0 \cdot 1 & 84 & 69\end{array}$

At such high concentrations of ferri $\left[{ }^{3} \mathrm{H}\right]$ exochelin, uptake of ${ }^{3} \mathrm{H}$ was sensitive to the compounds previously shown to inhibit ${ }^{55} \mathrm{Fe}$ uptake (see Table 1); i.e. $\mathrm{NaN}_{3}(30 \mathrm{~mm}), \mathrm{KCN}$ (10 $\mathrm{mm}), \mathrm{CCCP}(0 \cdot 1 \mathrm{~mm}), \mathrm{DNP}(2 \mathrm{mM})$ and $\mathrm{HgCl}_{2}(0.1 \mathrm{~mm})$ all produced immeasurably low rates of ${ }^{3} \mathrm{H}$ uptake which were therefore less than $5 \%$ of the uninhibited activity. However, the external ferriexochelin concentration had been raised approximately 80 -fold to assay $\left[{ }^{3} \mathrm{H}\right]$ exochelin uptake, and when the inhibitor studies of ${ }^{55} \mathrm{Fe}$ uptake from ferriexochelin were repeated at similar external concentrations, a markedly lower sensitivity to the various inhibitors was observed (Table 2).

The data therefore suggest the operation of at least two processes for iron transport from ferriexochelin. The simplest interpretation suggests that one process operates at low external ferriexochelin concentrations, is inhibitor-sensitive and involves the uptake of the ferriexochelin complex. A second process predominates at high external ferriexochelin concentrations and this is inhibitor-insensitive and does not involve the uptake of exochelin.

\section{Evidence for alternative routes for iron uptake}

To seek further evidence for the existence of more than one component for iron transport, the initial rate of ${ }^{55} \mathrm{Fe}$ uptake from ferriexochelin was measured in response to increasing external substrate concentration from 1.25 to $125 \mu \mathrm{M}$. The results (Fig. 3) indicate that probably two components are operating for iron transport from ferriexochelin by irondeficiently grown cells. One process is saturable (at about $12.5 \mu \mathrm{M}$-ferriexochelin) and the other fails to saturate within the range of concentration used. In the presence of $\mathrm{NaN}_{3}$ $(30 \mathrm{~mm})$ the saturable component was eliminated (Fig. 3). In addition, at high external ferriexochelin concentration $(63.1 \mu \mathrm{M})$ the uptake of ${ }^{55} \mathrm{Fe}$ was inhibited by $80 \%$ when a 10 -fold excess of ferric salicylate was added $15 \mathrm{~s}$ before the ${ }^{55} \mathrm{Fe}$-exochelin. These results, which are in contrast to those obtained using $1.25 \mu \mathrm{M}^{-55} \mathrm{Fe}$-exochelin, suggest that ferric salicylate interferes with the second, inhibitor-insensitive component for iron transport from ferriexochelin by iron-deficiently grown cells.

This last result suggested that mycobactin may be involved in the second component for iron uptake. Iron-sufficiently grown cells, which contain only minimal amounts of mycobactin (see Discussion), were similar to iron-deficient cells in possessing a second, inhibitorinsensitive component for iron uptake at high concentrations of ${ }^{55} \mathrm{Fe}$-exochelin (Table 2). However, unlike iron-deficiently grown cells, they were not inhibited in the uptake of ${ }^{55} \mathrm{Fe}$ from ${ }^{55} \mathrm{Fe}$-exochelin $(63 \mu \mathrm{M})$ when unlabelled ferric salicylate was added in 10-fold excess even though ${ }^{55} \mathrm{Fe}$-salicylate is transported at such concentrations by iron-sufficiently grown cells. These results suggest that mycobactin was not involved in the second process. 

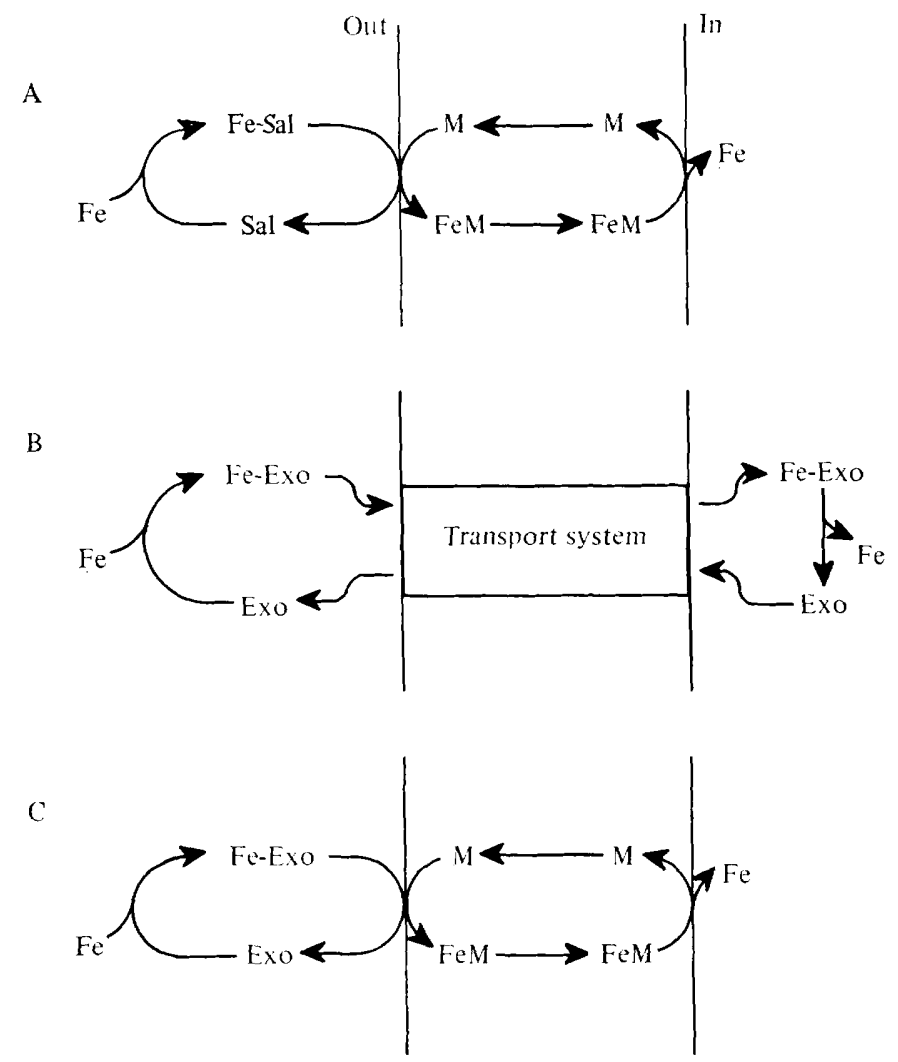

Fig. 4. Mechanisms of iron transport by Mycobacterium smegmatis: Sal, salicylate; Exo, exochelin; M, mycobactin.

(A) Salicylate-mycobactin system operating in iron-deficiently grown $M$. smegmatis, previously characterized by Ratledge \& Marshall (1972).

(B) Ferriexochelin transport system operating in both iron-deficiently and iron-sufficiently grown $M$. smegmatis at low, physiological ferriexochelin concentrations.

(C) Iron transport from ferriexochelin at high external concentrations, probably mediated by mycobactin in iron-deficiently grown $M$. smegmatis.

Thus, the second component for iron transport operating at high concentrations of ferriexochelin has different characteristics in iron-sufficiently grown cells from those in irondeficiently grown cells. Both types of cell, however, apparently share a common process for the uptake of iron from ferriexochelin at low external concentrations.

\section{DISCUSSION}

Iron uptake into $M$. smegmatis is a more complex process than hitherto believed and a number of separate routes may co-exist, as they do in Escherichia coli (Braun, 1978). Unlike $E$. coli, which synthesizes only one iron-chelating agent (enterochelin) and makes use of the presentation of other naturally occurring forms of iron for its alternative pathways, $M$. smegmatis and other mycobacteria produce three iron-chelating agents - salicylic acid, exochelin and mycobactin. Only mycobactin occurs exclusively in the cell (Ratledge \& Marshall, 1972). The previously described route of iron uptake via mycobactin (see Fig. 4A, and Ratledge \& Marshall, 1972) depended upon 'soluble' iron, in the form of ferric salicylate, being presented to cells. Though other aromatic acids can substitute for salicylate and also transfer iron to mycobactin, neither ferric citrate, ferric EDTA nor ferric oxalate 
can do so (Ratledge et al., 1974). Iron from ferrous sulphate is also rapidly taken up by mycobactin (oxidation may occur prior to or upon complex formation) when freshly prepared solutions are added to established iron-deficient cultures of $M$. smegmatis, that is, before polymeric forms of iron have been able to form (McCready \& Ratledge, 1978). However, since inhibition studies suggest that mycobactin is not involved in the uptake of iron from ferriexochelin at low concentrations, a novel and independent route for iron uptake is now recognized.

This novel iron transport system was seen in both iron-deficiently and iron-sufficiently grown cells despite the fact that exochelin synthesis is repressed during iron-sufficient growth. Although culture filtrates from iron-sufficiently grown cells have a small but detectable capacity to solubilize iron (Macham \& Ratledge, 1975), the amount of exochelin present has not been measured. Iron acquisition is, however, necessary no matter what the concentration of extracellular iron and thus the exochelin-mediated system is deduced to be prevalent at all concentrations of extracellular iron.

As a result of investigating the inhibitor-sensitivity of both ${ }^{55} \mathrm{Fe}$ and $\left[{ }^{3} \mathrm{H}\right]$ exochelin uptake, we propose that iron uptake from ferriexochelin at low external concentrations involves simultaneous uptake of both ligand and metal. In this respect, the uptake would be similar to the uptake of other ferric siderophores in other bacteria, for example, ferrischizokinen transport in Bacillus megaterium, ferriaerobactin in Aerobacter (Klebsiella) aerogenes 62/1, and ferrienterochelin in Escherichia coli (Arceneaux et al., 1973; Frost \& Rosenberg, 1973). (This could be confirmed if $\left[{ }^{14} \mathrm{C}\right]-$ or $\left[{ }^{3} \mathrm{H}\right]$ exochelin of high specific activity could be prepared as this would permit double-labelling experiments at low ferriexochelin concentrations.) The mechanism of uptake is also similar to other ferric siderophore transport systems in showing sensitivity to a wide range of metabolic inhibitors. The sensitivity to uncouplers and electron transport inhibitors is similar to that shown for ferrienterochelin transport in E. coli (Pugsley \& Reeves, 1977), suggesting that iron transport is dependent upon the creation and maintenance of an energized membrane state. Lack of uptake at $4{ }^{\circ} \mathrm{C}$ may also reflect the need for metabolism. Similarly, under anaerobic conditions, when respiration and oxidative phosphorylation are prevented, no uptake is observed. The ability of thiol reagents to block uptake suggests the involvement of $-\mathrm{SH}$ groups in the overall process, although in view of the lack of specificity of these compounds it is not possible to define their site of action. However, Ernst \& Winkelmann (1977) have reported that the binding sites for ferricoprogen on the surface of intact cells of Neurospora crassa can be labelled to a high degree by $\left[{ }^{14} \mathrm{C}\right] \mathrm{NEM}$. If the similarity between the ferriexochelin system and other siderophore uptake systems is extended, one would expect that there will also be specific binding proteins on the mycobacterial cell surface as for N. crassa, E. coli (Hancock et al., 1976; Braun, 1978) and Salmonella typhimurium (Luckey \& Neilands, 1976; Neilands, 1977).

The uptake of iron from ferriexochelin at low external concentrations is considered to be characteristic of the in vivo physiological situation, and occurs via a high-affinity system, with a $K_{\mathrm{m}}$ of approximately $6 \mu \mathrm{M}$. (This value, obtained from the data of Fig. 3, is only approximate due to the difficulty in estimating the saturating ferriexochelin concentration in the presence of interference by the non-saturable, inhibitor-insensitive system.) This $K_{\mathrm{m}}$ is similar to that reported in other systems (Lankford, 1973; Wiebe \& Winkelmann, 1975). The mechanism of iron release and the fate of the desferriexochelin are unknown. The intact ligand may be excreted, as occurs with schizokinen in B. megaterium (Arceneaux et al., 1973), aerobactin in $A$. aerogenes (Arceneaux et al., 1973) and ferrichrome in E. coli (Leong \& Neilands, 1976). Alternatively, exochelin could be hydrolysed, as occurs with enterochelin and the fusarinines (O'Brien et al., 1971; Emery, 1976). In these cases the degradation products can be detected in the medium. If this occurs in M. smegmatis it could explain the number of exochelins found in the culture filtrates, some of which are not active in iron transport though they do still bind iron. A scheme for this high-affinity, inhibitor-sensitive process of iron uptake is depicted in Fig. 4 B. 
A further, different process for iron uptake from ferriexochelin at high, and probably non-physiological, concentrations was recognized by its insensitivity to the various inhibitors. As ferri $\left[{ }^{3} \mathrm{H}\right]$ exochelin uptake at the same high concentration was extremely sensitive to these metabolic inhibitors the process cannot involve simultaneous uptake of metal and ligand. The inhibition of iron uptake by ferric salicylate under these conditions, using iron-deficiently grown cells, suggests that mycobactin may be the receptor for the transported iron (see Fig. 4C). This inhibition was not observed when iron-sufficiently grown cells were used, suggesting the operation of two different systems. However, since iron-sufficiently grown cells contain at most only $0.05 \%$ of the mycobactin of iron-deficiently grown cells (Ratledge \& Marshall, 1972), it is possible that the location and accessibility of this small concentration of mycobactin prevents observation of the salicylate inhibition phenomenon, especially if a binding site for ferriexochelin specifically facilitates exchange of iron between exochelin and mycobactin. It must, however, be stressed that this second exochelin system, for which parallels exist in other organisms, viz. uptake of ferric citrate by $N$. crassa (Winkelmann \& Zahner, 1973), may be non-physiological as it is unlikely that very high concentrations of ferriexochelin could suddenly arise in vivo.

Two major questions arise from this present work: the first, and more obvious, is what is the detailed mechanism of iron uptake from exochelin? This could be elucidated with a suitably isotopically labelled substrate. The second, more enigmatic, is what is the role of mycobactin if the physiological iron-sequestering agent, exochelin, does not transfer its iron to the cell via mycobactin?

Miss Jennifer Beaumont is thanked for her technical assistance. This work was supported by a research grant from the Science Research Council.

\section{REFERENCES}

Arceneaux, J. E. L., Davis, W. B., Downer, D. N., HAYDON, A. H. \& BYERS, B. R. (1973). Fate of labelled hydroxamates during iron transport from hydroxamate-iron chelates. Journal of Bacteriology 115, 919-927.

Braun, V. (1978). Structure-function relationships of the Gram-negative bacterial cell envelope. Symposia of the Society for General Microbiology 28, 111-138.

EMERY, T. (1976). Fungal ornithine esterases: relationship to iron transport. Biochemistry 15, 27232728.

Ernst, J. \& Winkelmann, G. (1977). An attempt to localize iron-chelate binding sites on cytoplasmic membranes of fungi. FEBS Letters 76, 71-76.

Frost, G. E. \& Rosenberg, H. (1973). The inducible citrate-dependent iron transport system in Escherichia coli $\mathrm{K}-12$. Biochimica et biophysica acta $\mathbf{3 3 0}$, 90-101.

Hancock, R. E. W., Hantke. K. \& Braun, V. (1976). Iron transport in Escherichia coli K-12: involvement of the colicin B receptor and of a citrate-inducible protein. Journal of Bacteriology 127, 1370-1375.

LANKFORD, C. E. (1973). Bacterial assimilation of iron. CRC Critical Reviews in Microbiology 2, 273-331.

LeONG, J. \& Neilands, J. B. (1976). Mechanisms of siderophore iron transport in enteric bacteria. Journal of Bacteriology 126, 823-830.

LuCKeY, M. \& NeILANDS, J. B. (1976). Iron transport in Salmonella typhimurium LT-2: prevention, by ferrichrome, of adsorption of bacteriophages ES18 and ES18.h1 to a common cell envelope receptor. Journal of Bacteriology 127, 1036-1037.

Macham, L. P. \& Ratledge, C. (1975). A new group of water-soluble iron-binding compounds from mycobacteria: the exochelins. Journal of General Microbiology 89, 379-382.

Macham, L. P., Ratledge, C. \& Nocton, J. C. (1975). Extracellular iron acquisition by mycobacteria: role of exochelins and evidence against the participation of mycobactin. Infection and Immunity 12, 1242-1251.

Macham, L. P., Stephenson, M. C. \& Ratledge, C. (1977). Iron transport in Mycobacterium smegmatis: the isolation, purification and function of exochelin MS. Journal of General Microbiology 101, 41-49.

McCready, K. A. \& Ratledge, C. (1978). Amounts of iron, haem and related compounds in $\mathrm{Myco}-$ bacterium smegmatis grown in various concentrations of iron. Biochemical Society Transactions 6, 421-423.

Midgley, M. \& Dawes, E. A. (1973). The regulation of transport of glucose and methyl $\alpha$-glucoside in Pseudomonas aeruginosa. Biochemical Journal 132, 141-154.

NeILANDS, J. B. (1977). Siderophores: diverse roles in microbial and human physiology. In Iron Metabolism, Ciba Foundation Symposium 51, pp. 107-124. Amsterdam: Elsevier. 
O'Brien, I. G., Cox, G. B. \& Gibson F. (1971). Enterochelin hydrolysis and iron metabolism in Escherichia coli. Biochimica et biophysica acta 237, 537-549.

Pugsley, A. P. \& Reeves, P. (1977). Uptake of ferrienterochelin by Escherichia coli: energydependent stage of uptake. Journal of Bacteriology 130, 26-36.

Ratledge, C. \& Hall, M. J. (1971). Influence of metal ions on the formation of mycobactin and salicylic acid in Mycobacterium smegmatis grown in static culture. Journal of Bacteriology 108, 312-319,

Ratledge, C. \& Marshall, B. J. (1972). Iron transport in Mycobacterium smegmatis: the role of mycobactin. Biochimica et biophysica acta $\mathbf{2 7 9}$, 58-74.

RATledGe, C. \& Winder F. G. (1962). The accumulation of salicylic acid by mycobacteria during growth on an iron-deficient medium. Biochemical Journal 84, 501-506.
Ratledge, C., Macham, L. P., Brown, K. A. \& Marshall, B. J. (1974). Iron transport in Mycobacterium smegmatis: a restricted role for salicylic acid in the extracellular environment. Biochimica et biophysica acta 372, 39-51.

SNow, G. A. (1970). Mycobactins: iron-chelating growth factors from mycobacteria. Bacteriological Reviews 34, 99-125.

Stephenson, M. C. \& Ratledge, C. (1978). The transport of iron from ferriexochelin by $\mathrm{Myco-}$ bacterium smegmatis. Biochemical Society Trans. actions 6, 423-425.

Wiebe, C. \& WinkelmanN, G. (1975). Kinetic studies on the specificity of chelate-iron uptake in Aspergillus. Journal of Bacteriology 123, 837842.

WinkelmanN, G. \& Zahner, H. (1973). Uptake of iron by Neurospora crassa. The specificity of iron transport. Archiv für Mikrobiologie 88, 49-60. 